\title{
Colonial and Neocolonial Domination and Alienation: Consequences and Strategies of Resistance in Ngugi Wa Thiong'o's and Mecere Githae Mugo's the Trial of Dedan Kimathi (1976)
}

\section{Babacar Diakhaté}

Laboratoire d'Études africaines et postcoloniales, Université Cheikh Anta Diop Dakar, Sénégal Email: diakhatebabacar83@hotmail.fr

\begin{abstract}
:
Many African political officials have become famous for their political actions, determination, and strong commitment against colonialism, imperialism and even neo-colonialism. In Kenya, Ngugi WA Thiong'o and Mecere Githae Mugo fictionalize the story of Dedan Kimathi. The Trial of Dedan Kimathi (1976) retraces the life of the hero, Kimathi, who leads the Mau Mau movement against British colonizers. Kimathi is imprisoned because of his own brother Wambararia who betrays his people to become free. Whites' collaborators and neo-colonial actors such as politicians, Business executives and the Church do not succeed to persuade Kimathi to accept the collaborationist option and stop the struggle.
\end{abstract}

Keywords:

colonialism; imperialism; neo-colonialism; anti-colonial struggle; freedom

\section{Introduction}

Nelson Mandela, with his A.N.C political party, the Pan-Africanist, Patrice Lumumba, Thomas Sankara, with his "Nationalism" theory, the historian-Anthropologist Cheikh Anta Diop, Kwame Nkrumah's "African Personality", Leopold Sedar Senghor's "Negritude" movement, Dedan Kimathi in Kenya, Mouammar Khadafy's "Pan Arabism" theory to name but a new, all devoted their lives to the liberation of Africa from European colonialists and imperialists. These pan-Africanists and their anti-colonial political agenda have been echoed by Africans' most emblematic writers. They represent ant-colonial heroes in their works of fiction such as in Chinua Achebe's A Man of the People, No Longer At Ease and Things Fall Apart, Peter Abrahams' Mine Boy, Nadine Gordimer's My Son's Story, Ngugi WA Thiong'o's Weep Not, Child, etc.

The Trial of Dedan Kimathi shows Kimathi's loyalty and faithfulness to his people during his struggle against repression. The aim of this article is to bring to light Kimathi's determination to lead his anti-colonial struggle despite his fellow citizens' betrayal and disloyalty. It also pinpoints the motivations of his people to turn themselves into "traitors" and play "the collaborationists" option". The first part is devoted to the troublesome colonial context in Kenyan and Kimathi's struggle against oppression. The second part displays the debasement of African values and the loss of "togetherness" and "commonness" motto. The last part focuses on neo-colonial actors such as politicians, Business executives and the Church. The anti-colonial movement's subterfuges to resist oppression will also be brought to light. 


\section{Review of Literatures}

\subsection{Troublesome Colonial Context}

In pre-colonial Africa, African people had a good socio-cultural order and a perfect political organisation. They considered themselves to be children of the same family. In The Trial of Dedan Kimathi, Ngugi WA Thiong'o and Mecere Githae Mugo accuse colonizers of the debasement of African traditional values and practices. They break the socio-political organization of Kenyan communities. Writers put: They used to dance these before the white colonialists came. In the arena... at Imitation... during funerals...during marriages...Then the colonialists came and the people danced a different dance (Wa Thiong'o and Mugo, 1976: 37). African ancestors promoted the survival of African values such as solidarity, loyalty, honour, pride, protection against premarital sex, virginity, self-discipline, preservation of the traditional practices, and respect for human dignity. These values seem to be fading away from the traditional African Society.

The colonialists' arrival in Africa engenders the shift of the populations from their traditional beliefs and behaviours to a new and unknown lifestyle, which systematically changes African virtues. Africans are running away from themselves and from their traditional past. This brings about the rapid intervention of some aspects of western values and cultures like individualism, disloyalty, materialism, homosexuality, sexual freedom, etc. Solidarity and love have been replaced by selfishness or individualism, spirituality is opposed to Materialism, Loyalty to Disloyalty. Isolation and loneliness have eroded human solidarity; etc. A colonial governor arrives. The dance now by all the groups together becomes one of fear and humiliation. They dance feverishly and then go off the stage followed by the stiff figure of colonial governor (Wa Thiong'o and Mugo, 1976: 37).

The Trial of Dedan Kimathi and Mine Boy by Peter Abrahams castigate the exploitive capitalist system of the colonizers in Kenya as well as in South Africa. In Wa Thiong'o and Mugo's novel, the Boy whose mother dies when giving birth to a baby drops out school and begs for money in the street. The Boy's father also dies in the industry out of haemorrhage. In the play, Mugo and Wa Thiong'o reveal the foreigner's subterfuge to put in conflict two relatives. In South Africa, during the Apartheid exploitive system, Chris and Johannes die in the mines in the eyes of their white bosses. Both books depict capitalist and apartheid systems meant for dehumanizing and exploiting people. The Boy reveals:

Father and I went to Nairobi. He found a job with a firm of Timber merchants. A tiny room: A tiny salary. Then I did not understand and I would steal from him, even the little that he earned for both of us. His ambition was to earn enough to come back to Nyeri and buy a piece of land. But he never made it. The machine cuts off his right hand... and he died of bleeding. No medical care from his employers. I was thrown out of the room he had rented (Wa Thiongo and Mugo, 1976: 19).

The Boy's desire to kill his sister for stealing his crumbs shillings shows that capitalism is the sources of human conflicts. Strangers come in Africa to eat Africans' food and leave the leftovers for African children:

Our people...tearing one another... and all because of the crumbs thrown at them by exploiting foreigners. Our food eaten and leftovers thrown to us- in our land, when we should have the whole share. We buy wood from our own forests; sweats on our own soil for the profit of our oppressors (Wa Thiongo and Mecere, 1976: 18). 
Colonizers break Kimathi's social justice in the forest. For Henderson, Kimathi's "Nyandarua" traditional justice should be modernized: Their bloody Kimathi is appearing in court at Nyeri today. This afternoon. He is going to get a proper court trial. Not like the jungles ones he used to stage in the forest. See how fair mzungu is? (Mugo and Wa Thiongo, 1976: 12). Because of colonialism, people no longer respect the traditional choices and decisions of wise people. In Sefi Atta's Swallow, the Oba of England chooses a husband for Tolani when she is in her mother's village, Makoku. Tolani refuses:

One day, I returned home to find my entire family gathered in our compound: my father, mother, uncles, aunts, Iya Alaro, and the elders included him (...). The palace wanted me to report as a wife the next day. I told my father, "I will not go". He asked, "what? .You disobey me twice? Taboo, you hear taboo...You refuse to marry the man I chose for you and now you refuse the palace. What kind of daughter is this? This one wants to stay in this compound until she becomes old (Atta, 2010:93).

Traditional responsibilities of wise people in African societies are restricted. Young women are victims of modernity. Tolani shows her iconoclastic attitudes to the community. She asserts:

The deputy dare not interfere, particularly in matters involving women. $\mathrm{He}$ knows that if he interferes, he will be well and truly cursed. He does not understand our ways and has never done us any good. He is always taking taxes and fining us. What does he know? (Atta, 2010: 94).

Language is of paramount importance of culture. It helps to understand to which group the character belongs. It is a means of domination that colonial missionaries use to perpetuate oppression. Aliou Sow points out linguistic influence:

From colonialism to neo-colonialism, the strong and permanent domination tool has been language(...) For young Africans, America means English language (Anglo-American new language), running an American way of life is synonymous with speaking English, listening to Rap and R'n'B music, rushing to the corner's fast food and wearing big pants (Sow, 2009:260).

\section{Discussion}

\subsection{Colonialism and Resistance \\ a. Colonial Weapons}

Colonizers came in foreign lands to divide the communities. They formed their own people, taught them their language and made them assimilated. In The trial of Dedan Kimathi, Kimathi is separated from his community. His own brother is among the whites' "collaborators". They are the intermediary between the colonisers and the autochthones. The love that Kenyans have for Kimathi pushes black collaborators to plan to kill him. Soldier says: Let me tell you, after the trial, after Kimathi is hanged, there will be no more fighting. It will be end of this bloody struggle (Wa Thiong'o and Mugo, 1976: 13).

In Things Fall Apart, colonisers find collaborators among the most influential persons in the Igbos to convert them into Christianity. They give the new converted pieces of lands and other privileges. This division contributes to the falling apart of the Igbo community and Okonkwo's failure. Kimathi's arrest and ill-treatment by colonizers is facilitated by his own brother, Wambararia: Kimathi's own brothers are wearing hoods, pointing out the terrorists and their supporters one by one... And the mothers who have lost their husbands and children might want to tear that beastly Kimathi to pieces (Wa Thiong'o and Mugo, 1976: 13). 
Colonialists' strategies to divide African people is also portrayed in Shimmer Chinodya's Dew in The Morning. Chinodya brings to light the division of two communities: the locals and the Derukas. The former represent the autochthone populations whose main activity is agriculture. They depend on their lands to survive. The latter are the displaced populations who have lived for a long time with colonizers. They gain advantage of white people's privileges. The conflicting tension between the locals and the Derukas helps colonisers to put hands on cultivating lands. Colonialists' manipulation is what Wa Thiong'o and Mugo depict:

What was one of those soldiers said? "The way the enemy makes us thirst to kill one another". How right he was! He must be one of the sons of the soil. Take the case of us peasants, for one. We are told we are Luo, you are Kalenjin, you are Maasai, and you are Kikuyu. You are a woman, you are a man, you are this, and you are that, you are the other :( after some thoughts): Yes. We are only ants trodden upon by heavy merciless elephants (Wa Thiong'o and Mecere, 1976: 14).

Violence is also among the weapons and strategies of colonisers. White collaborators soldiers consider the Mau-Mau anti-colonial movement as a terrorist association. According to them, the Mau-Mau are their main enemies. They are stubborn, courageous and radical:

European soldiers were catching people at night, and having taken them to the forest would release them and ask them to find their way back home. But when their backs were turned they would be shot dead in cold blood. The next day this would be announced as a victory over the Mau Mau (Wa Thiong'o, 1964: 84).

The paranoia that exists between European soldiers and the Mau Mau symbolizes the danger of the guerrilla war. Kimathi is very committed to defending his community and their properties. For him, Kenyans have done enough for the British people for defending them against Europe's and Asia's most powerful nations. Kenyans have to take over from British colonisers to rule their own country. A new wind of change has blown and British people have to leave their land. Kimathi stages:

With the British we have been losers all the way- Yes - but this is a new era. This is a new war. We have bled for you. We have fought your wars for you against the Germans, Japanese, and Italians. This time we shall bleed for our soil, for our freedom, until you let go (Wa Thiong'o, Mecere, 1976: 34).

\section{b. The Colonized Resistance Strategies}

In reaction to the British colonisers who take and loot Kenyans' soil and natural resources, Kimathi and all his loyalties resort to unity, brotherhood, Sisterhood and solidarity to fight the enemy. Mama tells: Instead of fighting against one another, we who struggle against exploitation and oppression, should give another strength and faith till victory is ours. United, our strength becomes the faith that moves mountains (Wa Thiongo and Mugo, 1976: 60). Thanks to loyalty and determination, the struggle can be won. Kimathi teaches: unity, drive out the enemy and control your, our riches, enjoy the fruit of your sweat (Wa Thiongo and Mugo, 1976: 18). The accusation of Kimathi's illegal possession of a gun by the British judge triggers off the population's uprising. The loyalists to Kimathi take to the street to perpetuate the struggle.Women in the resistance against oppression and for Kimathi's liberation is worth of praise: Mama tells a Boy:

There, outside the prison gates or outside the courtroom, or somewhere between the prison gates and the courtroom you will find a man selling oranges. He will be wearing a red shirt. He will be singing: "oranges cheap to-day! Thandaraita-aa". Give him this loaf of bread (Wa Thiongo and Mecere, 1976: 21). 


\section{c. Females' Contributions to Resistance}

Women's involvement in the struggle is essential as they can dissuade their husbands and children to join the resistance movement. Mama succeeds in initiating the young boy who steals and assaults in the street. She turns him into a very courageous combatant. Mama puts a gun within a loaf of bread and delegates the Boy to give it to Kimathi in prison. Women's implication in the struggle is fruitful because the gun in the bread causes the commotion in Kimathi's trial day. When Kimathi's friends and families betray the anti-colonial movement, women take over from "traitors" by wearing hoods. They pretend to be fruit sellers in the prison. The writers show:

A woman walks across the stage. She is between thirty and forty years old age

with a mature and youthful face strongly built...Fearless determination and a spirit of daring is her character... She is full of energy in her response to different roles and situations. A mother, a fighter, all in one (Wa Thiongo, Mecere, 1976: 8).

The initiation of Boys by females shows the $21^{\text {st }}$ century African Women' leadership. They are actors of development, they occupy the political positions that were exclusively reserved for man. In these last decades, women have been presidents, ministers, directors, etc. They are implicated in activism and the civil society.

\subsection{Actors of Neo-Colonialism}

Independence has not immediately announced the fulfilment of Africans' most cherished dreams of freedom, sovereignty, socio-political and economic satisfaction. Consequently, a new reality shows up, sparked by political disillusionment, injustice, poverty, social unrest, oppression, corruption, etc.

In The Trial of Dedan Kimathi, there are three categories of neo-colonial actors. Firstly, there are the politicians who do nothing to alleviate the populations' hard living conditions. They perpetuate what has been left by European colonizers. Instead of calling them "Black Skins White Masks" (1967) Wa Thiong'o and Mecere call them: "Black skins, colonial settlers' bearts"...New masters. We labor for you, pick coffee and tea for you. Is that why poor men died and continued to die in the forest? General Kago, Baimunge, Matenjagwo... and many brave sons are still locked in there (Wa Thiong'o and Mugo, 1976: 46-47). Post-independent African political leaders loot African natural resources and wrench the lands from their owners. The lack of cultivating lands leads African children to leave their countries for the West. They become candidates for clandestine emigration or terrorists.

Secondly, the presence of Banks and their administrators is depicted by the writers. The partnerships with banks make populations' financial situations to shift from bad to worse. The loans that must be paid with interests become unbearable for banks' clients. The administrators of banks display their comfort to the detriment of their poor customers: Time is money...we are from the bank, the Insurance companies, the industries you can call us...the representatives of the business community...I am the maker of modern Kenya. Who finance the railways? (Wa Thiongo and Mugo, 1976: 38).

Finally, religion is also influenced by colonialism. Like politicians and Business executives, priests are also among the collaborators of the British colonialists. The spiritual domination leads the priest to plan to "modernize" and "Africanize" the church. For Kimathi the priest betrays his people and collaborates with the whites. The priest tries to convince Kimathi to plead guilty and accept the collaborationist option. He uses the church as an alibi: We are now Africanizing the church. We want to see the Christ reflected in our culture. Drums in Church. African bishop. African moderators. African Cardinals (WA Thiongo and Mugo, 1976: 49). 
Kimathi's response to the Priest witnesses his courage, faith and loyalty to his people: I will fight to the better end. Protect our soil. Protect our people. This is what I, Kimathi WA Wachiuri, swore at initiation (Wa Thiongo, Mugo, 1976: 54).

\section{Conclusion}

Many African political figures were involved in independent struggles. While some of them chose pacific ways to liberate their people, others adopted violence to fight colonizers. In Kenya, the anti-colonial struggle became violent and bloody with the Mau-Mau movement. In The Trial of Dedan Kimathi, Ngugi WA Thiong'o and Mecere Githae Mugo dramatize the anti-colonial struggle in which Kimathi WA Wachiuri is the leader of the Mau Mau anticolonial movement. Kimathi considers himself as the Messiah from God to save his people. His imprisonment is facilitated by his brother, Wambararia. He betrays his people to become the colonialists' "collaborator". His brother's disloyalty and the actors of neo-colonialism such as the politicians, Business executives and the priest do not prevent Kimathi to lead his struggle. He depends on his loyal women, Boys and Girls to resist domination and perpetuate the combat.

\section{References}

Abrahams, Peter. (1946). Mine Boy, London: Heinemann.

Achebe, Chinua. (1958). Things Fall Apart. Heinemann.

Achebe, Chinua. (1960). No Longer At Ease. Heinemann.

Achebe, Chinua. (1966). A Man of the People. London: Heinemann.

Atta, Sefi, Everything Good Will Come. (2004). interlink book.

Atta, Sefi, Swallow. (2010). Interlink book.

Brown, Nicolas.(1999). "Revolution and Recidivism: The Problem of Kenyan History in the Plays of Ngugi WA Thiong'o", Research in African Literatures Indiana University Press, Volume 30, Number 4, PP. 56-76.

Coetzee, J. Maxwell. (1999). In the Heart of the Country. London: Vintage.

Coetzee, J. Maxwell. (2013). Disgrace. Penguin Books.

Chinodya, Shimmer, (2001). Dew in the Morning. London: Heinemann.

Essop, Ahmed. Hajji, (1993) S. Geok-lin Lim and N. Spencer, one world of literature (pp. 161-170), Boston, Massachussets: Houghton Mifflin company.

Fanon, Frantz (1969).Pour la Révolution Africaine, Paris François Maspero.

Fanon, Frantz. Black Skins White Masks, (1967) published originally in French as Peaux Noires, Masques Blancs (1952), New York: Crove Press.

Magel, E. A. (2014). "Symbolism and Regeneration in Ngugi WA Thiong'o's and Mecere Mugo's The Trial of Dedan Kimathi”, in Canadian Journal of African Studies/ Revue Canadienne des études africaines, Volume, 17, 1983-Issue 2, P.239-245.

Milingo, Emmanuel. The World in Between Gweru (1985), p.96, points out the fact that a vast number of Christians are ancestor worshippers and, for that matter, proud of it. I have experienced the same thing in my pastoral ministry as a Catholic priest. It is not notable that many Kenyans noted a similar feeling during the Otieno case in 1987.

Pobee, J. S. (1979). Towards and African Theology. Nashville, Tennessee, Abingdon, PP. 4345.

Sow, Aliou. "The Role of Foreign Languages in Peace Building in Africa", in Annales de la Faculté des Lettres et Sciences Humaines, N³9/A, 2009.p.260.

Seeman, Melvin, (1959). On the Meaning of Alienation. American Sociological Review, 24. 
Tenshak, Juliet. (2014). Dictatorship and Alienation in Sefi Atta's Everything Good Will Come, in LUMINA, Vol.25, No. 1, October, 2014, P. 6. Adapted from W. D. O. Nwaegbe (2013) Alienation and Literature, Indiana: Xlibris 46.

Wa Ngugi, Mukoma, (2013). Black Star Nairobi. Melville House.

Wa Thiongo'o, Ngugi, MECERE, Githae Mugo. (1976). The Trial of Dedan Kimathi, Nairobi.

Wa Thiongo, Ngugi, (1964). Weep Not, Child. Heinemann Educational Publishers. 